
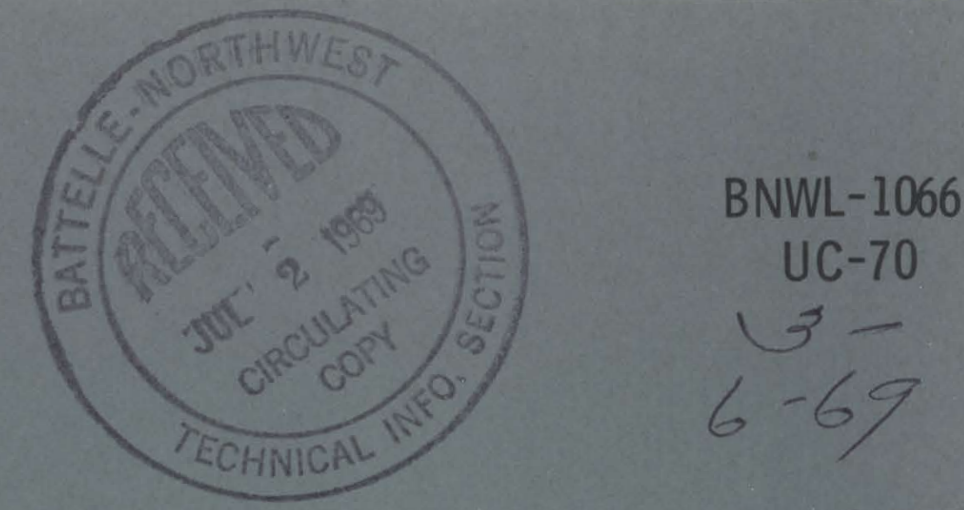

\title{
EVALUATION OF ATOMIZING NOZZLES FOR THE SPRAY SOLIDIFICATION OF RADIOACTIVE WASTE
}

June 1969

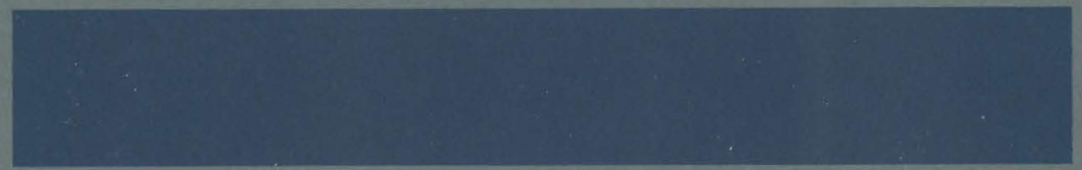

\section{AEC RESEARCH \& DEVELOPMENT REPORT}

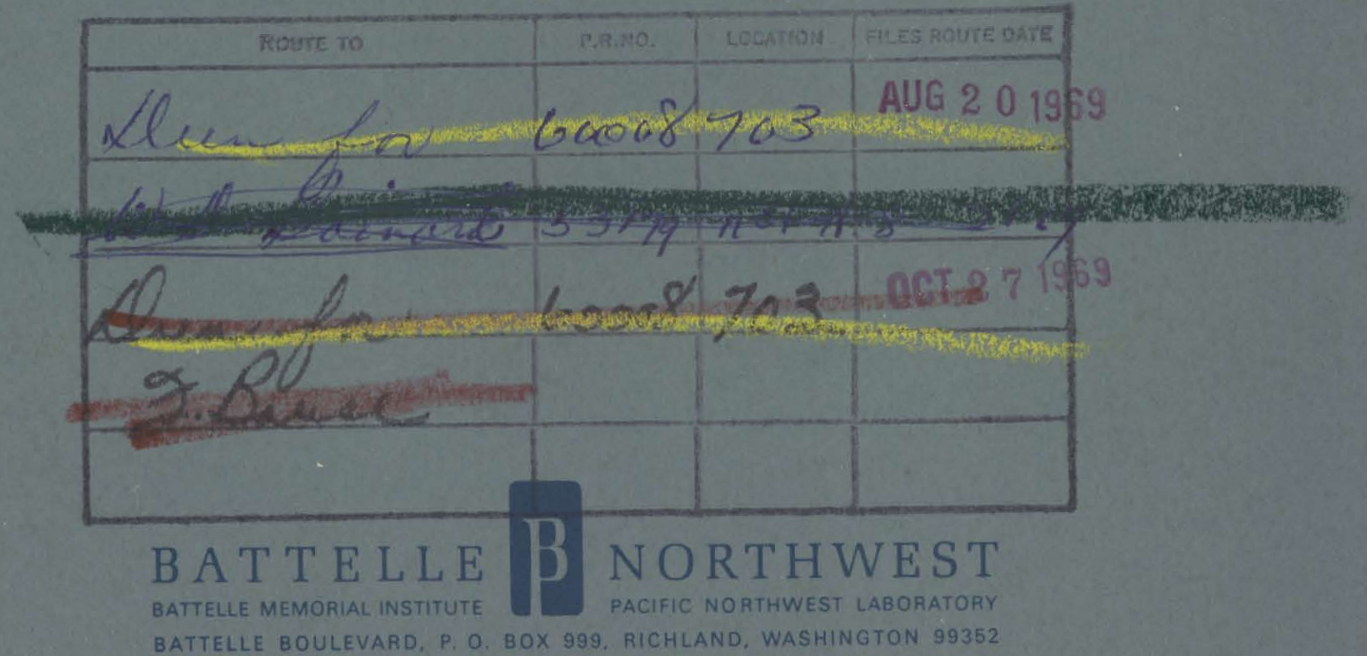




\title{
LEGAL NOTICE
}

This report was prepared as an account of Government sponsored work. Neither the United States, nor the Commission, nor any person acting on behalf of the Commission:

A. Makes any warranty or representation, expressed or implied, with respect to the accuracy, completeness, or usefulness of the information contained in this report, or that the use of any information, apparatus, method, or process disclosed in this report may not infringe privately owned rights; or

B. Assumes any liabilities with respect to the use of, or for damages resulting from the use of any information, apparatus, method, or process disclosed in this report.

As used in the above, "person acting on behalf of the Commission" includes any employee or contractor of the Commission, or employee of such contractor, to the extent that such emplayee or contractor of the Commission, or employee of such contractor prepares, disseminates, or provides access to, any information pursuant to his employment or contract with the Commission, or his employment with such contractor.

\author{
PACIFIC NORTHWEST LABORATORY \\ RICHLAND, WASHINGTON \\ operated by \\ BATTELLE MEMORIAL INSTITUTE \\ for the
}

UNITED STATES ATOMIC ENERGY COMMISSION UNDER CONTRACT AT(45-1)-1830 
Chemical Technology Department Chemistry and Metallurgy Division

$$
\text { with Appendices by }
$$

J. L. Jaech and R. L. Buschbom

Applied Mathematics Department Systems and Electronics Division 
BNWL - 1066

Printed in the United States of America Available from

Clearinghouse for Federal Scientific and Technical Information National Bureau of Standards, U.S. Department of Commerce Springfield, Virginia 22151

Price: Printed Copy $\$ 3.00 ;$ Microfiche $\$ 0.65$ 


\section{EVALUATION OF ATOMIZING NOZZLES FOR THE SPRAY SOLIDIFICATION OF RADIOACTIVE WASTE \\ J. D. Kaser}

\section{ABSTRACT}

Several atomizing nozzles were evaluated for use in the spray solidification process for radioactive waste by comparing spray drop size. Sprays were sampled by the drop capture method. An internal mix pneumatic atomizing nozzle was selected (Spraying Systems Company Setup No. 42). For this nozzle, the mass median drop diameter in micrometers, $\bar{x}$, increased with the ratio of liquid to air volumetric flow, $Q_{\ell} / Q_{a}$ according to the relation: $\bar{x}=29400\left(Q_{\ell} / Q_{a}\right)+18.9$. The drop sizes were distributed such that the dimensionless diameter $x^{*}=x / \bar{x}$ followed the special upper limit distribution:

$$
\frac{d v}{d y}=\frac{\delta}{\sqrt{\pi}} e^{-\delta^{2} y^{2}}
$$

$$
\text { where, } \begin{aligned}
\mathrm{y} & =\ln \left(\frac{\mathrm{ax}}{\mathrm{x}_{\mathrm{m}}-\mathrm{x}^{*}}\right) \\
\mathrm{v} & =\text { volume fraction of drops smäller than } \mathrm{x}^{*} \\
\delta & =0.826 \\
\mathrm{a} & =1 \\
\mathrm{x}_{\mathrm{m}} & =2
\end{aligned}
$$




\section{TABLE OF CONTENTS}

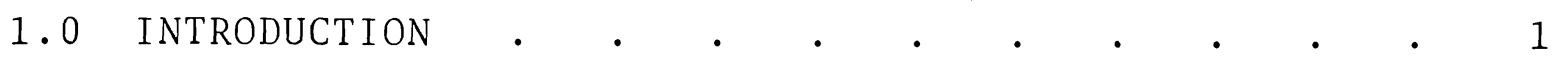

2.0 SUMMARY AND CONCLUSIONS $\quad . \quad \ldots \quad$ •

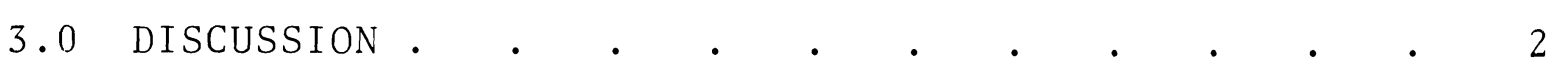

3.1 Experimental . . . . . . . . . . 2

3.1 .1 Apparatus and Technique . . . . 2

3.1 .2 Sources of Error . . . . . . . 4

3.1.3 Simulated Radioactive Waste Slurry . . 6

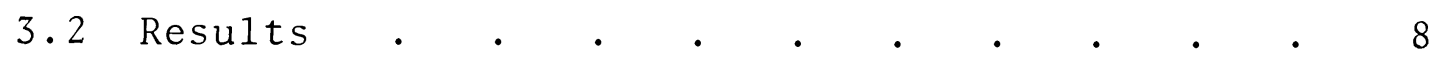

3.2.1 Nozzle Screening Tests . . . . . 8

3.2.2 Effect of Obstructions on Atomization . 8

3.2.3 Variation in Nozzle Performance Due to Manufacturing Tolerances . . . 10

3.2.4 Correlation of Drop Size with Air and Liquid Rates . . . . . . 10

3.2.5 Drop Size Distribution . . . . . 16

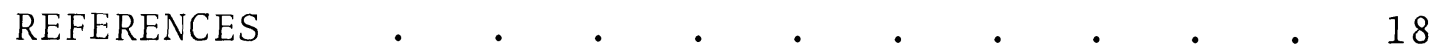

APPENDIX A Determination of Sample Size in Calculating Median Volume Percent

APPENDIX B Correlation of Liquid/Gas Mass Ratio and

Liquid/Gas Volume Ratio with Drop Size . . B.1 
BNWL- 1066

EVALUATION OF ATOMIZING NOZZLES FOR THE SPRAY SOLIDIFICATION OF RADIOACTIVE WASTES

J. D. Kaser

\subsection{INTRODUCTION}

The spray solidification process for the fixation of highly radioactive waste has been developed at the Pacific Northwest Laboratory and is being demonstrated on an engineering prototype scale. In.this process, radioactive waste solution is sprayed into the top of an externally heated drying chamber through a pneumatic atomizing nozzle. Many of the spray droplets hit the walls of the drying chamber. If the droplets are wet they may stick to the walls, building up a deposit which reduces the drying capacity and which may eventually fill the drying chamber.

In view of the importance of spray nozzle performance on the successful operation of the process, this work was undertaken (1) to evaluate several promising nozzles and choose the most suitable nozzle for the spray solidification equipment, and (2) to determine how spray drop size is affected by operating variables and nozzle size.

Because of the complex nature of pneumatic atomization, drop size must be determined experimentally and be empirically correlated with the variables affecting atomization. Therefore, a given correlation may accurately apply to only one kind of nozzle.

\subsection{SUMMARY AND CONCLUSIONS}

This study aided in the selection of a more satisfactory atomization nozzle for use in the spray solidification process and defined the atomization characteristics of the nozzle which was selected. Three internal mix atomizing nozzles were tested 
and found to produce equally uniform, finely atomized sprays while an external mix nozzle previously used in the process (Spraying Systems Co. Setup No. 5) produced a spray with a poorly atomized core. Spraying Systems Co. Setup No. 42 was selected for process use because it was most compatible with existing hardware.

The atomizing characteristics of Spraying Systems Setup No. 42 were studied in detail with the following results:

1) Neither internal nor external obstructions significantly affected atomization.

2) Simulated waste spray droplets were either the same size or smaller than water spray droplets at the same liquid and air volumetric flow rates.

3) The ratio of liquid rate to air rate appeared to be the only variable governing drop size in the range of flows investigated. Thus, the mass median drop diameter is a linear function of the ratio of liquid to air flow.

4) Dimensionless drop diameters followed a single distribution which was closely approximated by the upper limit equation of Mugele and Evans. (1)

\subsection{DISCUSSION}

\subsection{EXPERIMENTAL}

\section{1 .1 Apparatus and Technique}

Figure 1 illustrates how spray droplets were captured in an optical cell placed in a cylindrical holder with a shutter for admitting a controlled amount of spray. The optical cells were made by cementing short sections of plastic pipe (3/4 inch diameter by $1 / 8$ inch high) onto microscope slides. The bottom of each cell was coated either with high viscosity immersion oil or with dichlorodimethyl silane to prevent the spray droplets from wetting the bottom of the cell. For sampling water sprays, 


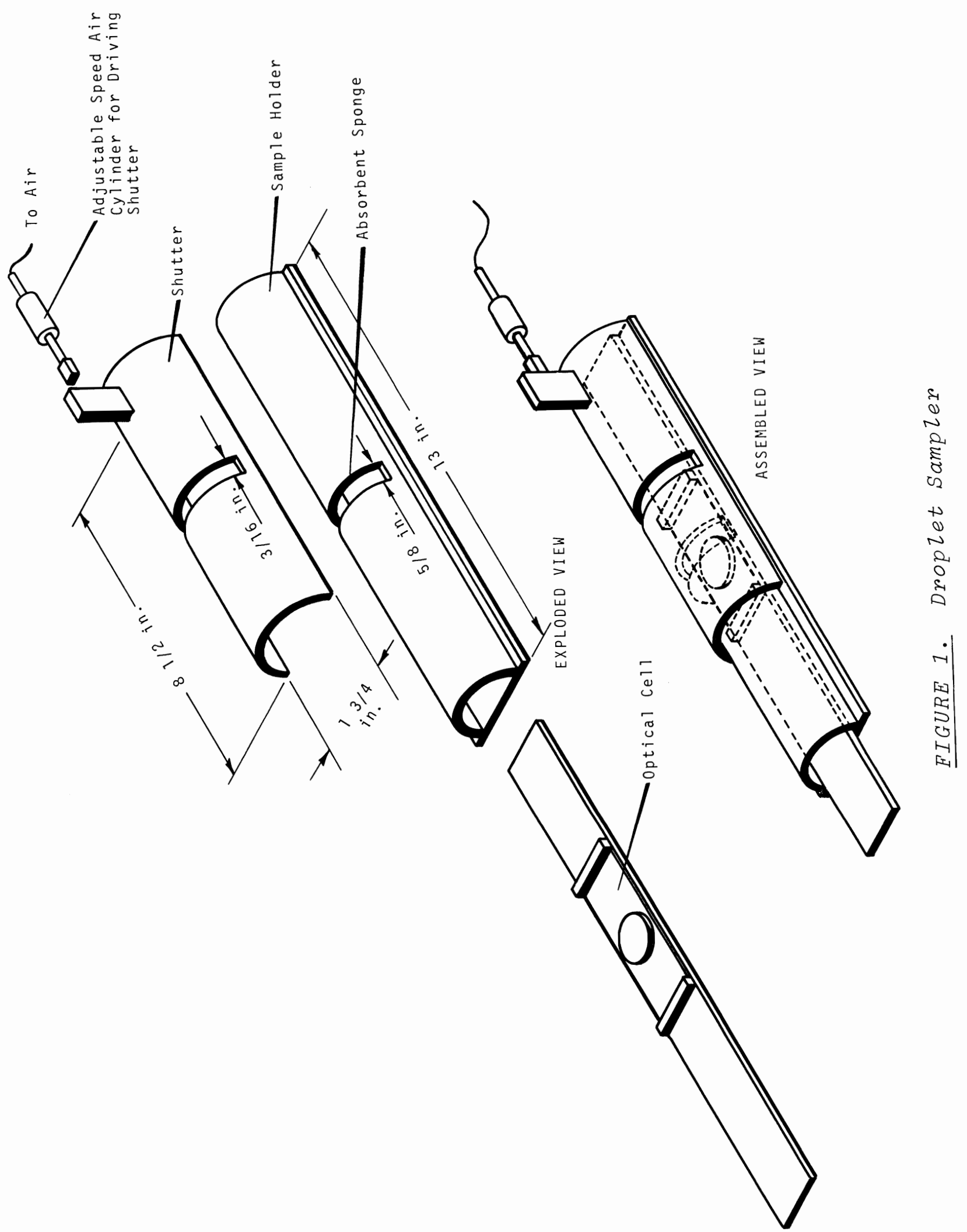


the cell was filled with kerosene to prevent evaporation of the captured droplets. This cover layer of kerosene was not used for sampling sprays of simulated waste solution because the droplets of solution coalesced rapidly on the surface of the kerosene. The droplets of simulated waste were captured on a layer of very high viscosity oil to prevent excessive flattening of the droplets. The drops of simulated waste did evaporate, but they left shells of the dissolved solid which were less than $5 \%$ smaller than the original liquid droplets.

Photomicrographs, magnified about 90 times, were taken of the sampled droplets. The droplets were then sized and counted from the photomicrographs. In all atomization tests, the spray was confined inside a cylindrical chamber 14 inches in diameter by 60 inches high. The sample cell holder was placed 44 inches directly below the spray nozzle.

\section{1 .2 Sources of Error}

There are several sources of error in the measurement of spray drop size distribution. A nonrepresentative sample may be obtained because the smaller droplets tend to flow around rather than enter the sample cell. Nevertheless, droplets down to 10 micrometers in diameter were collected. In this work the primary interest was in determining the size of the larger droplets produced, since they limit the drying capacity of the spray calciner. Therefore, complete sampling of the smallest droplets was not considered essential.

In early experiments with water sprays, it was noticed that drops moved around in the kerosene layer of the sample cell for several seconds before resting on the bottom of the cell. During the time the drops are moving around in the kerosene they could coalesce, producing a disproportionate number of larger droplets. To obtain some idea of the magnitude of coalescence, 
two solutions were sprayed into a single sample cell. Each solution contained a colorless component, either $\mathrm{FeCl}_{3}$ or KCNS, so that deep red droplets resulted when unlike droplets coalesced. (2) For a typical sampling density, 3 to $4 \%$ of the droplets were colored, which means the total fraction of all coalesced droplets was probably more than three times as great.

The effect of coalescence on apparent drop size was also estimated in another way. The apparent mass median diameter was correlated with droplet density in the sample cell for a group of water spray samples taken with the same spray nozzle at the same operating conditions. The data are plotted in Figure 2 along with the regression line. Although the drop coalescence is a random process and therefore cannot be exactly predicted, the resulting error was at least reduced by using the correlation in Figure 2 to estimate a correction when a kerosene cover layer was used.

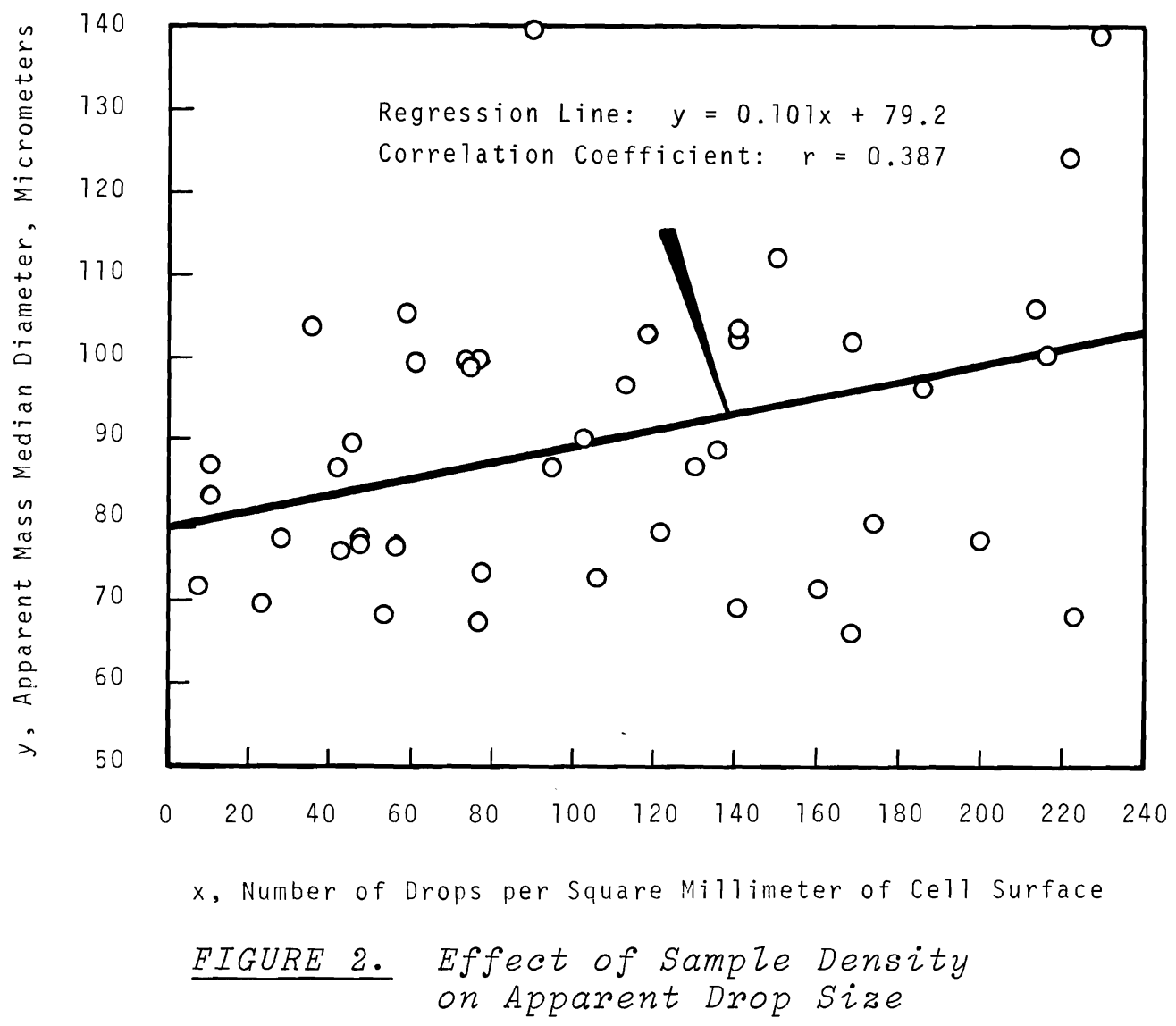


BNWL - 1066

When sprays of simulated waste solut:on were sampled, a kerosene layer was not required. Thus, 1j.ttle or no coalescence could take place in the sample after capture.

Another more obvious source of error is that spray sample size may be too small to accurately represent the entire spray. The magnitude of the error depends on both. the number of drops sampled and on how the drop sizes are distributed.

The error due to sample size can be estimated by determining empirically how the apparent mass median diameter varies with the number of droplets counted, or the error can be calculated if the size distribution is known. J. L. Jaech calculated the standard deviation in mass median diameter for some typical droplet distributions (see Appendix A). In order to decide how many drops to count per sample, one must balance the value of increased precision against the time and expense of counting large samples. In this work the variation in the mass median diameter between samples was about $\pm 20 \%$ even when 1000 to 4000 drops were counted. Therefore, it was not profitable to count more than about 300 drops per sample since the value of the precision gained by a large count was nullified by the variation between replicate samples.

The variation in mass median diameter from sample to sample may have been caused both by inadvertent variations in flow rates, coalescence, or sampler positioning.

In view of the large experimental error, observed trends in the data were always tested for statistical significance. 3.1.3 Simulated Radioactive Waste Slurry

The composition of the simulated waste slurry used in atomization tests is shown in Table 1 . 

TABLE 1. Composition of Simulated PW-2
Wastes with Added Flux

\begin{tabular}{|c|c|}
\hline Ion & g moles/liter \\
\hline $\mathrm{Fe}^{+3}$ & 0.445 \\
\hline $\mathrm{Cr}^{+3}$ & 0.024 \\
\hline $\mathrm{Ni}^{+2}$ & 0.027 \\
\hline $\mathrm{Al}^{+3}$ & 0.251 \\
\hline $\mathrm{Na}^{+}$ & 0.93 \\
\hline $\mathrm{SO}_{4}^{-2}$ & 0.88 \\
\hline $\mathrm{PO}_{4}^{-3}$ & 1.62 \\
\hline $\mathrm{SiO}_{3}^{-2}$ & 0.01 \\
\hline $\mathrm{MoO}_{4}^{-2}$ & 0.079 \\
\hline $\mathrm{Sr}^{+2}$ & 0.016 \\
\hline $\mathrm{Ba}^{+2}$ & 0.02 \\
\hline $\mathrm{K}^{+}$ & 0.042 \\
\hline Rare earths & 0.12 \\
\hline $\mathrm{ZrO}_{2}^{+2}$ & 0.065 \\
\hline $\mathrm{Ru}^{+4}$ & 0.003 \\
\hline $\mathrm{Mn}^{+2}$ & 0.003 \\
\hline $\mathrm{Co}^{+2}$ & 0.0074 \\
\hline $\mathrm{Cu}^{+2}$ & 0.002 \\
\hline $\mathrm{NO}_{3}^{-}$ & 5.37 \\
\hline $\mathrm{Li}^{+}$ & 1.17 \\
\hline $\mathrm{Ca}^{+2}$ & 0.60 \\
\hline
\end{tabular}


BNWL- 1066

The slurry had a density of $1.25 \mathrm{~g} / \mathrm{ml}$ and contained 19 vol\% or 47 wt $\%$ suspended solids. The suspended solid matter consisted of rod-shaped crystallites about 5 micrometers in diameter by 60 micrometers 1 ong.

\subsection{RESULTS}

\subsubsection{Nozzle Screening Tests}

The most immediate goal of this study was to find a nozzle which performed better than the external mix pneumatic atomizing nozzle previously used in the spray calciner. This external mix nozzle often produced an excessive accumulation of partially dried feed at the bottom of the spray chamber, and laboratory tests (3) showed an uneven distribution of liquid in the spray with most of the liquid in a narrow central stream consisting of droplets 1000 micrometers or larger.

A number of nozzles were screened to eliminate those producing sprays with poorly atomized cores. Spray droplet sizes were measured for the three nozzles produring the most uniform sprays. The results of these spray drop neasurements are shown in Table 2. There was no significant dif:erence in mass median drop diameter among the three nozzles.

An internal mix nozzle, Spraying Systems Co. Setup No. 42 , was chosen to replace the external mix nozzle in the spray calciner, primarily because it was most compatible with existing hardware. After this nozzle was installed in the spray calciner, deposition was reduced to an acceptable le:vel.

\subsubsection{Effect of Obstructions on Atomization}

Spray solidification experience has shown that the outside of the nozzle often becomes encrusted with dried feed and that solid particles sometimes lodge in the internal liquid-air mixing chamber. Simple tests were performed to see whether these crusts seriously affected atomization. An external crust was 
simulated with ceramic cement. The opening in the simulated crust for the spray was $3 / 8$ inch in diameter and $1 / 2$ inch long which was representative of openings in actual nozzle crusts.

\section{TABLE 2. Comparison of Nozzles at Constant Air and Liquid Rates}

$$
\text { Air Rate } \quad=11,600 \mathrm{l} / \mathrm{hr} \text { at } 75^{\circ} \mathrm{F} \text { and } 1 \text { atmosphere }
$$

Liquid Rate $=15 \mathrm{l} / \mathrm{hr}$

Liquid: Simulated $\mathrm{PW}-2$ Waste

Nozzle

Spraying

Systems Co.

No. 42

Spraying

Systems Co.

No. 5

Sprayco

F3106

Sprayco

$5 \mathrm{BM}$
Mass Median Drop Diameter, micrometers

\section{6}

52

50

52

50

$>1000$

64

56

52

48

51

75

47

54

56

25
$>1000$

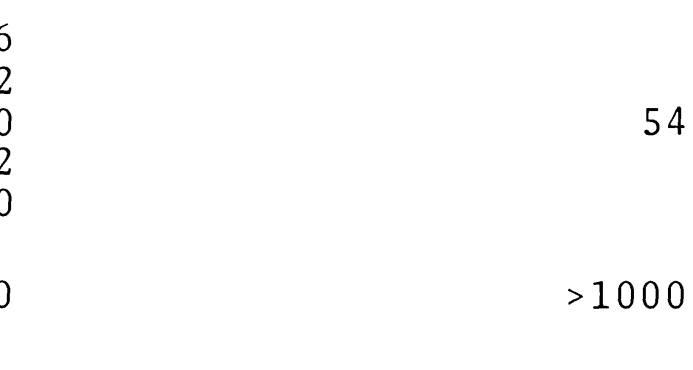

54

56

51
Average Mass Median Drop Diameter, micrometers

An internal obstruction was simulated by lodging a piece of wire, $1 / 32$ inch in diameter by 1 inch long, against the inside wall of the air orifice. As the data in Table 3 indicate, neither the external crust nor the internal obstruction had a significant effect on drop size. 


\section{TABLE 3. Effect of Nozzle obstructions \\ (Results of triplicate tests.)}

Air Rate $=14,200 \mathrm{l} / \mathrm{hr}$ at $75^{\circ} \mathrm{F}$ and 1 atmosphere

Water Rate $=20 \mathrm{l} / \mathrm{hr}$

\begin{tabular}{|c|c|c|}
\hline Obstruction & $\begin{array}{c}\text { Mass Median } \\
\text { Drop Diameter, } \\
\text { micrometers } \\
\end{array}$ & $\begin{array}{l}\text { Average Mass } \\
\text { Median Diameter, } \\
\text { micrometers }\end{array}$ \\
\hline None & $\begin{array}{l}42 \\
49 \\
41\end{array}$ & 44 \\
\hline $\begin{array}{l}\text { Externa1 } \\
\text { Crust }\end{array}$ & $\begin{array}{l}50 \\
42 \\
37\end{array}$ & 43 \\
\hline $\begin{array}{l}\text { Internal } \\
\text { Obstruction }\end{array}$ & $\begin{array}{l}46 \\
40 \\
34\end{array}$ & 40 \\
\hline
\end{tabular}

3.2.3 Variation in Nozzle Performance Due to Manufacturing Tolerances

The question arises whether there may be enough dimensional variation between nozzles of the same model to cause appreciable changes in atomization performance. In order to arrive at a partial answer, three different Spray Systems Co. No. 42 nozzles were tested at the same atomizing conditions. Four determinations of. mass median drop size were made with each nozzle. The experimental results are shown in Table 4. It was concluded that there was no statistically significant differences in the drop sizes produced by each nozzle.

3.2.4 Correlation of Drop Size with Air cnd Liquid Rates

Most investigations to date suggest the drop sizes from pneumatic nozzles primarily depend on gas and liquid flow rates, the relative velocity of the gas with respect to the liquid, and on the physical properties of both fluids such as density, viscosity, and interfacial tension. 
BNWL - 1066

\section{TABLE 4. Nozzle Reproducibility}

Nozzle Type: Spraying Systems Co. Setup No. 42 Air Rate $=11,600 \mathrm{l} / \mathrm{hr}$ at $75^{\circ} \mathrm{F}$ and 1 atmosphere Water Rate $=20 \mathrm{l} / \mathrm{hr}$

\begin{tabular}{ccc} 
Nozzle & $\begin{array}{c}\text { Mass Median } \\
\text { Drop Diameter } \\
\text { micrometers }\end{array}$ & $\begin{array}{c}\text { Average Mass } \\
\text { Median Diameter, } \\
\text { micrometers }\end{array}$ \\
\cline { 2 - 3 } A & $\begin{array}{c}\text { yo } \\
\text { A }\end{array}$ & \\
A & 79 & 83 \\
A & 85 & \\
B & 75 & \\
B & 87 & \\
B & 63 & \\
B & 79 & \\
C & & \\
C & 80 & \\
C & 78 & \\
C & 126 & \\
& 95 &
\end{tabular}

Subsonic atomizing air velocity was estimated from the cross sectional area of the nozzle orifice $0.01227 \mathrm{in}^{2}$ ) and the volumetric gas flow rate at ambient conditions $\left(75^{\circ} \mathrm{F}\right.$ and 1 atmosphere). Since the nozzle orifice was convergent, the upper limit to the atomizing air velocity was assumed to be the sonic velocity for air at $75^{\circ} \mathrm{F}(1136 \mathrm{ft} / \mathrm{sec})$. The liquid velocity was calculated from the cross sectional area of the liquid orifice $\left(0.0077 \mathrm{in}^{2}\right)$ and the volumetric flow rate of the liquid.

The mass median drop size did not correlate with the atomizing air velocity relative to the liquid but did show a strong dependence on the ratio of liquid to gas flow rates both on a mass basis and on a volume basis. Since the mass median diameter appeared to vary linearly with the flow ratios, straight lines were fitted to the data by the method of least squares. 
BNWL - 1066

When mass flow ratios were used, two lines were required to correlate the data: one for water and one for simulated PW-2 wastes. When volume flow ratios were used, there was no significant difference in the regression lines For the two liquids; therefore a single line could be used.

It should be noted at this point that some waste slurries may atomize quite differently from water. Limited data obtained from another batch of simulated $\mathrm{PW}-2$ waste solution showed appreciably smaller droplets than those produced by the main batch of simulated waste. When the solic.s were removed by centrifuging, the drop sizes approached those for water and for the main batch of simulated waste. This special batch of waste contained more solids than the main batch (30 vol\% versus 19 vol\%). This drop size data is plotted on Figure 3 for comparison with the main body of data.

The volumetric flow rate of the gas was estimated by assuming that the gas was at $75^{\circ} \mathrm{F}$ and 1 atmosphere pressure, the ambient conditions in the laboratory. Using the gas volumetric flow rate at ambient conditions to calculate volume flow ratios seems reasonable since high speed photographs indicated that the bulk of the atomization takes place outside the nozzle. Figure 3 shows the correlation of drop size with volume flow ratios, and Figure 4 shows the drop size correlation with mass flow ratios. The data plotted in these figures cover 1 quid flows ranging from 5 to $43 \mathrm{l} / \mathrm{hr}$ and gas flows ranging from 5000 to $18,900 \mathrm{l} / \mathrm{hr}$ at $75^{\circ} \mathrm{F}$ and 1 atmosphere. The standard residual deviations in the drop diameter from the correlation lines ranged from 13 to 15 micrometers. Statistical details are given in Appendix $B$.

It is interesting to compare the data with previously published correlating equations. One of the oldest and best known correlations is that of Nukiyama and Tanasawa: (4) 
BNWL-1066

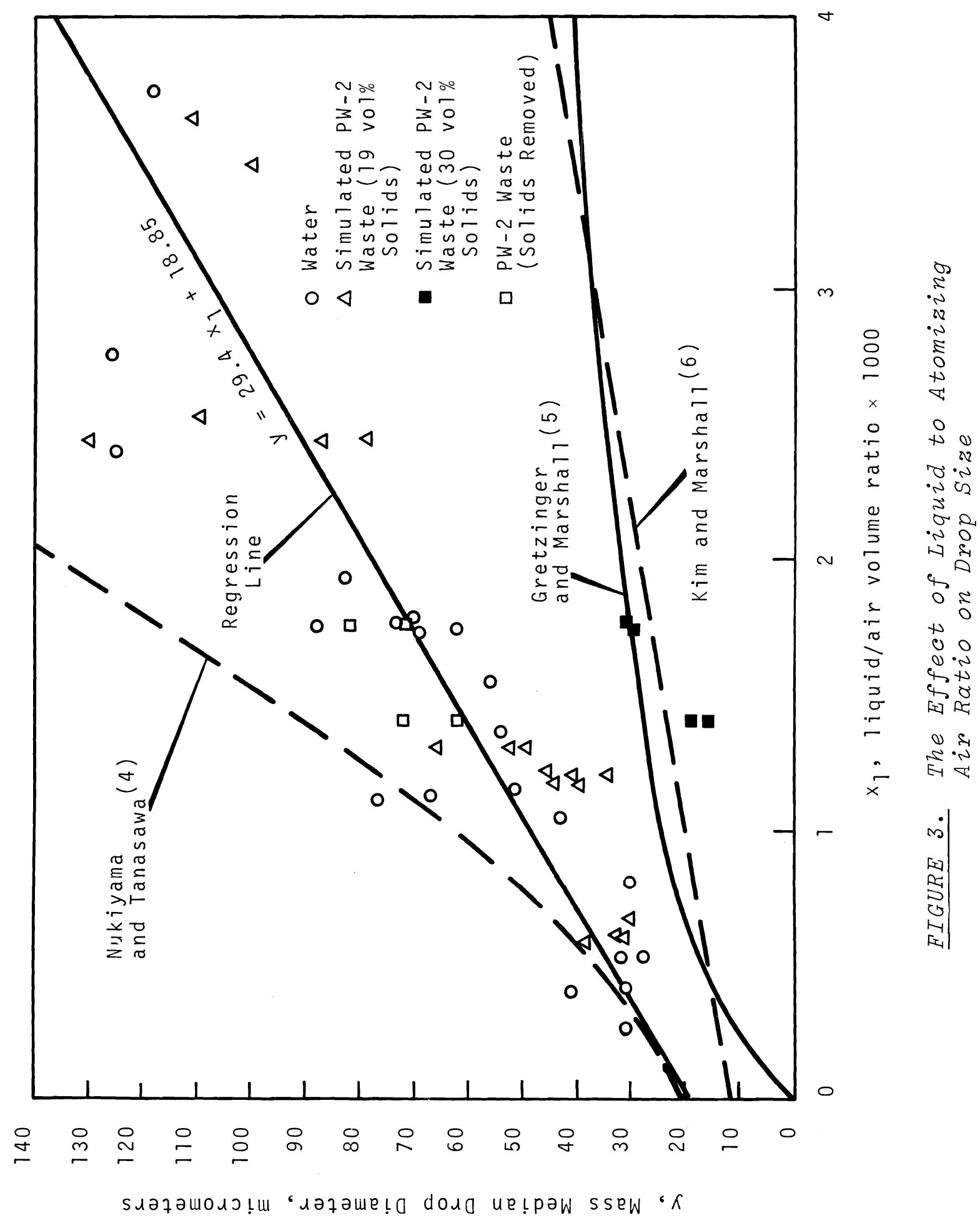


BNWL-1066

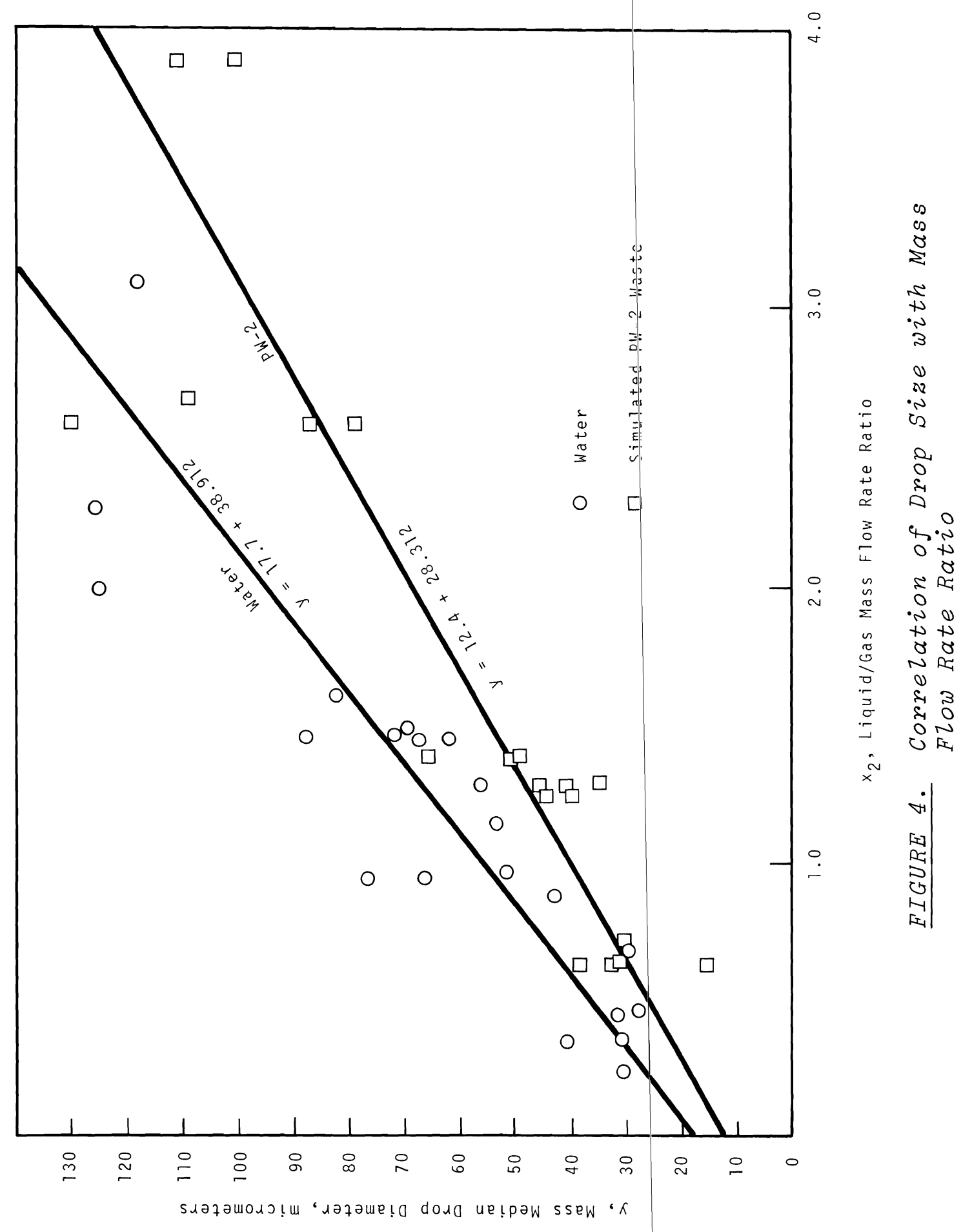




$$
x_{32}=\frac{1920}{v}\left(\frac{\sigma}{\rho}\right)^{0.5}+597\left(\frac{\mu}{\sqrt{\sigma \rho}}\right)^{0.45}\left(\frac{1000 Q_{\ell}}{Q_{a}}\right)^{1.5}
$$

where $x_{32}=$ Sauter mean diameter

$$
\begin{aligned}
Q_{l} / Q_{a}= & \text { ratio of liquid to gas volume flow rates } \\
v= & \text { relative velocity of the gas with respect to } \\
& \text { the liquid, ft/sec } \\
\sigma= & \text { surface tension, dynes } / \mathrm{cm} \\
\mu= & \text { liquid viscosity, poise } \\
\rho= & \text { liquid density in } \mathrm{g} / \mathrm{cm}^{3}
\end{aligned}
$$

This correlation was developed using data from sma11 internal mix nozzles at subsonic atomizing air velocities. This equation is therefore not strictly applicable to most of the data considered here where the air velocity was sonic. The Nukiyama-Tanasawa equation is plotted on Figure 3 for the water-air system. The equation was adjusted to correlate mass median diameter by multiplying by 1.44 the ratio of mass median diameter to Sauter mean diameter. This ratio $\bar{x} / x_{32}$ was obtained by fitting the experimental drop size distribution to the upper limit function proposed by Mugele and Evans (1) and then calculating the value of the ratio from their Equation 10.1 .

As can be seen in Figure 3 , the Nukiyama-Tanasawa equation agrees we11 with the data when $1000 \mathrm{Q}_{\ell} / \mathrm{Q}_{\mathrm{a}}$ is 1 ess than one. Otherwise the equation predicts too rapid an increase of drop size with the volumetric flow rate. Other equations by Gretzinger and Marsha11 (5) and by Kim and Marsha11 (6) strictly apply to small external mix nozzles. Both of their equations predict drop sizes that are too sma11. Because these equations are empirical, the disagreement is not surprising. 
BNWL - 1066

\subsubsection{Drop Size Distribution}

The method of Kim and Marshall (6) was used to plot the volume distribution of dimensionless drop sizes $\left(x / x_{m}\right)$ for both water and simulated $\mathrm{PW}-2$. The data appeared to be grouped along a single curve as shown in Figure 5. The Rosin-Rammler, lognormal and upper limit size distribution functions were compared with the generalized data, and it was found that the special upper limit function of Mugele and Evans ( $(t)$ best described the data. The upper limit function, which emphasizes the existence of a maximum drop diameter $x_{m}$, states that the dimensionless drop diameter y defined as:

$$
y=\ln \frac{a x}{x_{m}-x}
$$

is normally distributed according to the relation:

$$
\frac{d v}{d y}=\frac{\delta}{\sqrt{\pi}} e^{-\delta^{2} y^{2}}
$$

where $\mathrm{a}=$ arbitrary parameter

$\mathrm{v}=$ volume fraction of droplets having diameter smaller than $\mathrm{x}$

$x=$ droplet diameter

$\mathrm{x}_{\mathrm{m}}=$ maximum droplet diameter

$\delta=$ size distribution parameter

$\mathrm{y}=$ dimensionless function of $\mathrm{x}$

$\pi=$ natural constant $(3.141 \ldots)$

When this function was fitted to the data in Figure 5 (the solid curve), the following values for the distribution parameters were found.

$$
\begin{aligned}
\delta & =0.826 \\
a & =1 \\
x_{m} & =2
\end{aligned}
$$


Thus, the upper limit equation indicates that there is a maximum drop diameter which is twice as large as the volume or mass median diameter.

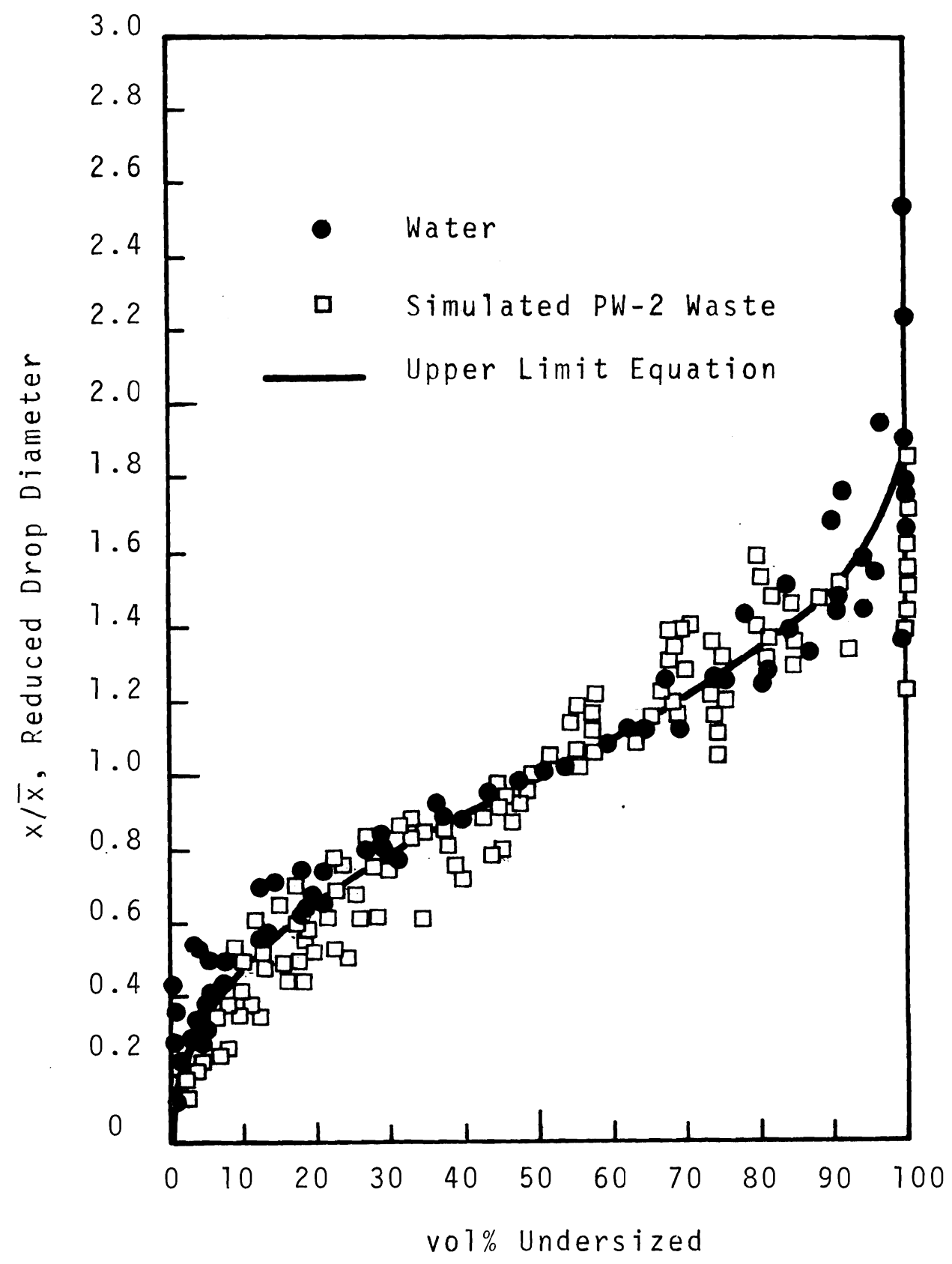

FIGURE 5. Dimensionless Drop Size Distribution 


\section{REFERENCES}

1. R. A. Mugele and H. D. Evans. "Droplet Size Distribution in Sprays," Ind. and Eng. Chem., vol. 43, no. 6, p. 1319. 1951 .

2. E. H. Lucassen-Reynders. Kolloid Zeitschrift, vol. 197, pp. 137-142. 1964 .

3. W. R. Bond and J. D. Kaser. "Spray Nozzle Atomization Studies," Quarterly Progress Report Research and Development Activities Fixation of Radioactive Residues, BNWL-434, pp. 12-14. Battelle-Northwest, Richland, Washington, June 1967.

4. S. Nukiyama and y. Tanasawa. Trans. Woc. Mech. Engrs. (Japan), 4-6 Reports 1-6 (1938-40). Translated by E. Hooc for Defense Research Board, Department of National Defense, Canada, 10M-9-47 (393), H.Q. 2-0-264-1, March 18, 1950.

5. J. Gretzinger and $W . R$. Marshazz, Jr. "Characteristics of Pneumatic Atomization," A.I.Ch.E. Journal, vol. 7, no. 2, p. 312. 1961 .

6. K. Y. Kim and W. R. Marshazl, Jr. Drcp Size Distributions from Pneumatic Atomizers. Paper presented at the 58th Annual A.I.Ch.E. Meeting, Philadelphia, December 1965. 
BNWL - 1066

APPENDIX A

DETERMINATION OF SAMPLE SIZE

IN CALCULATING MEDIAN VOLUME PERCENT

by

J. L. Jaech 
Where the derivatives are evaluated at the means, var $y_{\alpha}=\frac{p_{\alpha}\left(1-p_{\alpha}\right) v_{\alpha}^{2}}{n}$ is the variance of $y_{\alpha}$, and $\operatorname{cov}\left(y_{\alpha}, y_{\beta}\right)=$ - $\frac{\mathrm{p}_{\alpha} \mathrm{p}_{\beta} \mathrm{V}_{\alpha} \mathrm{V}_{\beta}}{\mathrm{n}}$ is the covariance between $\mathrm{y}_{\alpha}$ and $\mathrm{y}_{\beta}$. These two expressions follow from sampling theory for the multinomial probability distribution.

The following partial derivatives are found:

$$
\begin{aligned}
\frac{\delta Q}{\delta y_{\alpha}} & =-\frac{1}{2 y_{j+1}} \quad \text { for } \alpha=1,2, \ldots j \\
\frac{\delta Q}{\delta y_{\alpha}} & =\frac{1}{2 y_{j+1}} \quad \text { for } \alpha=j+2, \ldots k \\
\frac{\delta Q}{\delta y_{j+1}} & =\frac{1}{2}\left(\frac{\sum_{\alpha=1}^{j} y_{\alpha}-\sum_{\alpha=j+2}^{k} y_{\alpha}}{y_{j+1}^{2}}\right)
\end{aligned}
$$

Thus,

$$
\begin{aligned}
4 \operatorname{var} Q \approx & \frac{1}{y_{j+1}^{2}}\left[\sum_{\alpha=1}^{k} \operatorname{var} y_{\alpha}-\operatorname{var} y_{j+1}\right] \\
& +\left(\frac{\left.\sum_{\alpha=1}^{j} y_{\alpha}-\sum_{\alpha=j+2}^{k} y_{\alpha}\right)^{2}}{y_{\alpha+1}^{2}}\right)^{\operatorname{var} y_{j+1}} \\
& +\frac{2}{y_{j+1}^{2}}\left[\begin{array}{l}
\sum_{\alpha=1}^{j} \operatorname{cov}\left(y_{\alpha}, y_{\beta}\right) \\
\beta>\alpha
\end{array}\right] \\
& \left.+\frac{2}{y_{j+1}^{2}}\left[\begin{array}{l}
\alpha=j+2 \\
\beta>\alpha \\
j
\end{array} \operatorname{cov}_{\alpha}, y_{\beta}\right)\right]
\end{aligned}
$$

A. 3 


$$
\begin{aligned}
& -\frac{2}{y_{j+1}^{2}}\left[\sum_{\substack{\beta=1 \\
\alpha=j \\
\beta=j+2}} \operatorname{cov}\left(y_{\alpha}, y_{\beta}\right)\right] \\
& -\frac{2}{y_{j+1}^{3}}\left[\sum_{\alpha=1}^{j} y_{\alpha}-\sum_{\alpha=j+2}^{k} y_{\alpha}\right] \sum_{\alpha=1}^{j} \operatorname{cov}\left(y_{\alpha}, y_{j+1}\right) \\
& +\frac{2}{y_{j+1}^{3}}\left[\sum_{\alpha=1}^{j} y_{\alpha}-\sum_{\alpha=j+2}^{k} y_{\alpha}\right] \sum_{\alpha=k+2}^{k} \operatorname{cov}\left(y_{\alpha}, y_{j+1}\right) .
\end{aligned}
$$

Finding the variance of $Q$ is a formidable task by hand calculation. A computer program has been written to perform the calculation. Input to the computer consists of the $\mathrm{D}_{i}$ and the $\mathrm{p}_{i}$. In normal usage, the problem is to determine how large a sample to draw in order to estimate $Z$ with a desired precision. Of course, the exact values for the $p_{i}$ will not be known, otherwise there would be no need to sample. However, some idea of the droplet diameters is usually available a priori, and tinis will generally be sufficient to estimate the required sample size. If no such a priori information is available, one can draw a preliminary sample, perform the calculations, and see how many additional observations are required.

It should be noted that in the formula for the variance of $Q$, it is necessary to know the $p_{i}$ in order to evaluate it. For the problem discussed in the previous paragraph, this information is available. In another application, one has a set of data recorded and wants to find the variance of $\hat{Z}$ for that set. In such a case, estimates $p_{i}$ are used in the formulas in place of the $\mathrm{p}_{\mathrm{i}}$ themselves. 
As a final note, in the computer program, the quantity labelled "var. of Q" does not contain the sample size $\underline{n}$ in the formulas for var $y_{i}$ and $\operatorname{cov} y_{i}, y_{j}$. This enables us to find the variance of $Z$ as a function of $n$ by simply dividing "var. of Q" by $n$.

Examp1e

A set of data is as follows:

\begin{tabular}{rrr}
\multicolumn{1}{c}{ Interval } & & \multicolumn{1}{c}{$x_{i}$} \\
$1.0-1.0$ & & 648 \\
$1.5-2.0$ & & 196 \\
$2.0-2.5$ & 68 \\
$2.5-3.0$ & 69 \\
$3.0-3.5$ & 64 \\
$3.5-4.0$ & 58 \\
$4.0-5.0$ & 86 \\
$5.0-6.0$ & 54 \\
$6.0-7.0$ & 54 \\
$7.0-8.0$ & 14 \\
$8.0-9.0$ & 1 \\
$9.0-10.0$ & 9 \\
$10.0-11.0$ & 1 \\
& & 1364
\end{tabular}

With $\hat{\mathrm{p}}_{i}=\mathrm{x}_{\mathrm{i}} / \mathrm{n}$, the pertinent computer calculations are as follows:

$$
\begin{aligned}
& j \quad=9 \\
& D j \quad=D_{9}=6.0 \\
& D_{j+1}-D_{j}=D_{10}-D_{9}=1.0
\end{aligned}
$$




$$
\begin{aligned}
& \frac{M-W_{j}}{W_{j+1}-W_{j}}=0.161 \\
& \hat{Z}=6.0+(0.161)(1.0)=6.161 \\
& n \operatorname{var.~of~Q~}=23.3313 \\
& n=1364, \text { and } \\
& \text { var. of } Q=0.017105 \\
& \operatorname{var.~of~} \hat{Z}=(1.0)^{2} \text { var. of: } Q=0.017105 \\
& \quad \sigma \hat{Z}=\sqrt{0.017105}=0.131
\end{aligned}
$$

For these data, $n=1364$, and

Therefore, with $95 \%$ confidence, the true value of $z$ lies in the interval

$$
5.899<Z<6.423
$$

The effect of different sample sizes can be found by observing the behavior of

$$
\sigma \hat{z}=\sqrt{23.3313 / \mathrm{n}}
$$

The plot of $\sigma \hat{z}$ versus $n$ is a straight: line on log-log paper, so it is a simple matter to construct the relationship. 
As a final note, in the computer program, the quantity labelled "var. of $Q$ " does not contain the sample size $\underline{\mathrm{n}}$ in the formulas for var $y_{i}$ and $\operatorname{cov} y_{i}, y_{j}$. This enables us to find the variance of $Z$ as a function of $n$ by simply dividing "var. of Q" by $\mathrm{n}$.

$\underline{\text { Examp } 1 \mathrm{e}}$

A set of data is as follows:

\begin{tabular}{rrr}
\multicolumn{2}{c}{ Interva1 } & \multicolumn{1}{c}{$x_{i}$} \\
$0-1.0$ & 648 \\
$1.0-1.5$ & 196 \\
$1.5-2.0$ & 68 \\
$2.0-2.5$ & 42 \\
$2.5-3.0$ & 69 \\
$3.0-3.5$ & 64 \\
$3.5-4.0$ & 58 \\
$4.0-5.0$ & 86 \\
$5.0-6.0$ & 54 \\
$6.0-7.0$ & 54 \\
$7.0-8.0$ & 14 \\
$8.0-9.0$ & 1 \\
$9.0-10.0$ & 9 \\
$10.0-11.0$ & 1 \\
\hline & & 1364
\end{tabular}

With $\hat{p}_{i}=x_{i} / n$, the pertinent computer calculations are as follows:

$$
\begin{aligned}
& j \quad=9 \\
& D_{j}=D_{9}=6.0 \\
& D_{j+1}-D_{j}=D_{10}-D_{9}=1.0
\end{aligned}
$$




$$
\begin{aligned}
& \frac{M-W_{j}}{W_{j+1}-W_{j}}=0.161 \\
& \hat{Z}=6.0+(0.161)(1.0)=6.161 \\
& n \text { var. of } Q=23.3313
\end{aligned}
$$

For these data, $\mathrm{n}=1364$, and

$$
\begin{aligned}
\text { var. of } Q & =0.017105 \\
\text { var. of } \hat{Z} & =(1.0)^{2} \text { var. of: } Q=0.017105 \\
\sigma_{\hat{Z}} & =\sqrt{0.017105}=0.131
\end{aligned}
$$

Therefore, with $95 \%$ confidence, the true value of $\mathrm{Z}$ 1ies in the interval

$$
5.899<Z<6.423
$$

The effect of different sample sizes can be found by observing the behavior of

$$
\sigma_{\hat{Z}}=\sqrt{23.3313 / \mathrm{n}}
$$

The plot of $\sigma_{\hat{z}}$ versus $n$ is a straight line on log-log paper, so it is a simple matter to construct the relationship. 
APPENDIX B

CORRELATION OF LIQUID/GAS MASS RATIO

AND LIQUID/GAS VOLUME RATIO WITH DROP SIZE

by

R. L. Buschbom 


\section{APPENDIX B \\ CORRELATION OF LIQUID/GAS MASS RATIO \\ AND LIQUID/GAS VOLUME RATIO WITH DROP SIZE \\ by \\ R. L. Buschbom}

Drop size is expressed as a linear function of liquid/gas mass ratio or liquid/gas volume ratio. The mean value of $Y$ is a linear function of $X$, and the deviations from the mean line are normally distributed with mean zero and a residual standard deviation of $\sigma_{y \cdot x}$. Thus our model is

$$
y=\alpha+\beta x+\varepsilon
$$

where $\varepsilon$ has a normal distribution with zero mean and standard deviation $\sigma_{y \cdot x}$. Estimates of $\alpha, \beta$ and their standard errors $\sigma_{\alpha}, \sigma_{\beta}$, and $\sigma_{y \cdot x}$ are $a, b, s_{a}, s_{b}$ and $s_{y} \cdot x$ respectively. The numerical values for these estimates for the various liquid/ gas cases are given in Table B.1. Parameter $\mathrm{n}$ is the sample size, and parameter $r$ is the simple correlation coefficient between drop size (y) and the liquid/gas ratio (x).

A comparison of the correlation coefficients $r_{y} \cdot x_{1}$ and $r_{y \cdot x_{2}}$ for each 1 iquid/gas case indicates that they are not significantly different. This means that the liquid/gas mass ratio predicts the drop size as well as the 1 iquid/gas volume ratio. This is also indicated by the residual standard deviations $s_{y \cdot x_{1}}$ and $s_{y \cdot x_{2}}$ for each 1 iquid/gas case because they are approximately equal.

The next question to be asked is, "Can one regression line be used for all observation?" It seems reasonable to try to use one regression line for the water/air and PW-2/air data for drop size regressed on the liquid/gas mass ratio and another regression line for the same two cases only with drop size regressed on the liquid/gas volume ratio. 
The $F$ statistic is used to test the one regression line hypothesis for drop diameter correlated with mass ratio. The resulting $F$ value is 11.37 . The probability of an $F$ value greater than 11.37 with 2 and 38 degrees of freedom is less than 0.005 . This means that we reject the hypothesis that one regression line can be used for all these observations at the 0.05 level of significance. Next, we want to know if the reason two lines should be used is because there is a significant difference between the slopes 38.917 and 28.315 . The $F$ statistic is used to test this hypothesis, and the resulting $F$ value is 3.75 . The probability of an F value greater than 3.75 with 1 and 38 degrees of freedom is approximately 0.06 , which means that we accept the hypothesis that the slopes are not significantly different at the 0.05 level of significance. Therefore, the reason the hypothesis of one regression line is rejected is because the pooled estimate of the slope assuming $\beta_{1}=\beta_{2}$ is significantly different from the slope of the line that passes through the means of the two sets of data. Again, the F statistic is now used to test the one regression line hypothesis for drop size versus volume ratio, and the resulting $F$ value is 2.57 . The probability of an F value greater than 2.57 is approximately 0.10 , which means that we accept the hypothesis that one regression line can be used for all the observations at the 0.05 level of significance. The estimates for the regression line are

\begin{tabular}{cr} 
Parameter & Estimate \\
\cline { 2 - 2 } $\mathrm{a}$ & 18.850 \\
$\mathrm{~s}_{\mathrm{a}}$ & 4.545 \\
$\mathrm{~b}$ & 2.936 \\
$\mathrm{~s}_{\mathrm{b}}$ & 0.254 \\
$\mathrm{~s}_{\mathrm{y} \cdot \mathrm{x}}$ & 15.323
\end{tabular}


TABLE B.1. Drop Size versus Liquid/Gas Mass Ratio and Liquid/Gas Volume Ratio

\section{Drop Size versus Liquid/Gas Mass Ratio $\left(x_{i}\right)$}

\begin{tabular}{|c|c|c|c|c|}
\hline Parameter & Water/Air & Water/Argon & Water/Helium & $\mathrm{PW}-2 / \mathrm{Air}$ \\
\hline$n$ & 22 & 6 . & 4 . & 20 . \\
\hline a & 17.719 & -28.108 & 17.478 & 12.430 \\
\hline $\mathrm{s}_{\mathrm{a}}$ & 5.806 & 15.771 & 6.547 & 6.470 \\
\hline $\mathrm{b}$ & 38.917 & 102.102 & 11.050 & 28.315 \\
\hline$s_{b}$ & 4.238 & 11.824 & 0.874 & 3.344 \\
\hline$s_{y} \cdot x_{1}$ & 13.399 & 5.531 & 7.906 & 14.717 \\
\hline$r_{y} \cdot x_{1}$ & 0.899 & 0.974 & 0.994 & 0.894 \\
\hline
\end{tabular}

Drop Size versus Liquid/Gas Volume Ratio $\left(x_{2}\right)$

$\underline{\text { Parameter }}$ Water/Air Water/Argon Water/Helium $\underline{\text { PW-2/Air }}$

\begin{tabular}{crrrr}
$\mathrm{n}$ & 22 & 6 & 4 & \multicolumn{1}{c}{20} \\
$\mathrm{a}$ & 22.953 & -28.776 & 17.423 & 12.391 \\
$\mathrm{~s} a$ & 5.982 & 14.770 & 6.551 & 6.476 \\
$\mathrm{~b}$ & 2.994 & 6.194 & 6.671 & 3.005 \\
$\mathrm{~s}_{\mathrm{b}}$ & 0.370 & 0.669 & 0.527 & 0.355 \\
$\mathrm{~s}_{\mathrm{y} \cdot \mathrm{x}_{2}}$ & 14.789 & 5.172 & 7.906 & 14.721 \\
$\mathrm{r}_{\mathrm{y} \cdot \mathrm{x}_{2}}$ & 0.875 & 0.977 & 0.994 & 0.894
\end{tabular}




\section{DISTRIBUTION}

No. of

Copies

OFFSITE

1

AEC Chicago Patent Group

AEC Division of Technical Information Extension

5

AEC Division of Reactor Development and Technology C. N. Bartlett

W. G. Belter

W. H. McVey

A. J. Pressesky

W. H. Regan

2

AEC Idaho Operations Office

P. 0. Box 2108

Idaho Falls, Idaho 83401

K. K. Kennedy

B. L. Schmalz

1 Allied Chemical Corporation

Nuclear Fuels Department

P. 0. Box 70

Morristown, New Jersey 07960

R. L. Newman

3

Argonne National Laboratory

S. Lawroski

$\mathrm{J}$. Loeding

R. C. Voge 1

1 Atomic Energy Commission

Minister of Defense

Rehovoth, Israe 1

Yehuda Feige

4

\begin{tabular}{l} 
Atomic Energy of Canada Limited \\
\hline C. A. Mawson \\
I. L. Ophe1 \\
L. C. Wats on \\
J. Woolston
\end{tabular}


No. of Copies

5

Atomic Energy Research Establishment

Harwe11, Didcot, Berks, England

R. H. Burns

H. J. Dunster

W. H. Hardwick

K. D. B. Johnson

W. Wild

Australian Atomic Energy Commission

Research Establishment

Private Mail Bag

Sutherland, New South Wales, Australia

M. G. Bailie, Chemical Engineering Section

R. C. P. Cairns

L. Keher

Brookhaven National Laboratory

L. P. Hatch

E. J. Tuthil1

Center for Nuclear Studies

P. 0. Box 6, Fontenay-aux-Poses

(Seine), France

R. Bonniaud

F. Laude

J. Pomerola

P. J. Regnaut

J. Sauteron

Center for Nuclear Studies

P. O. Box 269

Grenoble (Isere), France

M. G. Wormser, Chemistry Division

3 Center for Nuclear Studies

P. 0. Box 2, Saclay

Gif-sur-Yvette

(Seine-et-Oise), France

C. Gailledreau

A. Menoux

Andre J. Raggenbass

2 Center for Study of Nuclear Energy (C.E.N.)

Mo1, Belgium

L. Baetsle

P. Dejonghe 
No. of

Copies

1

Commissaire Boite

Postale No. 149

Paris (15 $3 \mathrm{~m} 3)$, France

F. Dumahe 1

1 Comitato Nazionale per 1'Euergia Nucleare

Divisione di Protezione Sauitaria e Contro11i

Viale Regina Margherita 125

Roma, Italy

Ferruecio Gera

1

Commissariat a $L^{\prime}$ Energie Atomique

Cadarache, France

P. E. Pottier

1

6

1

1

The E. F. MacDonald Company

Touramerica Division

New York, New York

Fred Herber-Oettgen

1

EURATOM

Casse1la Postale No. 1

Ispra, Italy

M. Lindner

1

EURATOM

53 Rue Be11iard

Brusse1s, Belgium

Pierre Kruys

2

Eurochemic Library

Mo1, Be1gium 
No. of

Copies

1

European Nuclear Energy Agency 38 Boulevard Suchet

Paris 16, France

I. G. K. Williams, Deputy Director

1

General Electric Company

Fuel Recovery Operation

283 Brokaw Road

Santa Clara, Calif. 95050

R. G. Barnes

1

George Washington University

Washington, D. C.

C. R. Naeser

1

Geotechnical Corporation

Box 28277, Dallas, Texas

D. W. B. Heroy

1 Grupo de Combusitbles Irradiados

Junta de Energia Nuc1.

Div. de Mat, Civdat Univ.

Madrid 3 , Spain

Federico de Lova Soria

$1 \quad$ Gulf General Atomic

P. O. Box 608

San Diego, California

92112

J. J. Shefcik

1 Hahn-Meitner Institut

100 Glienicker Street

1 Berlin 39, Germany

Hans W. Levi

1 Harvard University

Cambridge, Massachusetts

H. A. Thomas, Jr.

3

Idaho Nuclear Corporation

J.A. Buckham

C. M. Slansky

B. R. Wheeler

1 Illinois State Geological Survey Division

Urbana, I11inois

J . C. Frye 
No. of

Copies

3

India Atomic Energy Establishment

Trombay Engineering Hall No. 5

Bombay 73, India

Keshave Chandra

Jitender D. Sehal

K. T. Thomas

1

Jersey Enterprises, Inc.

Joseph Building

Richland, Washington

L. B. Torobin

3

Johns Hopkins University

513 Ames Ha11

Baltimore, Md.

21218

J. Geyer

W. A. Patrick

A. Wolman

1

Karlsruhe Nuclear Research Center

Decontamination Dept.

75 Karlsruhe

Siemensallee 83, West Germany

Helmut Krause

1 Karlsruhe Nuclear Research Center

Waste Storage Dept.

Leopoldshafen/Bd.

Max-P1andk-Str. 12 ,

West Germany

H. F. Ramdohr

$1 \quad$ KFA

Director of Waste Treatment

Jue1ich, Germany

S. Rottay

1 Lawrence Radiation Laboratory, Berkeley (AEC)

Technical Information Division Library

1 Lawrence Radiation Laboratory, Livermore (AEC)

Technical Information Division Library

1 Los Alamos Scientific Laboratory (AEC) 
No. of

Copies

1

Mining Academy Clausthal

Petrology, Minerology

E Economics Geology, Dept.

Siemensalle, West Germany

H. F. A. Borchert

1 Minister of Federal Property

Const. Dept

Bad Godesberg, West Germany

G. M. K. KIinke

1 Monsanto Company

Inorganic Chemicals Division

$800 \mathrm{~N}$. Lindbergh Blvd.

St. Louis, Missouri 63166

K. Y. Kim

Mound Laboratory (AEC)

S. Freeman

J. J. Goldin

1 MPR Associates, Inc.

815 Connecticut Avenue, N. N. Washington, D.C. 20006

Theodore Rockwe11, III,

Chairman, AIF Safety Task Force

1 National Lead Company

111 Broadway

New York, New York 10006

Stephen Brown

1 Nationa1 Research Council

2101 Constitution Avenue

Washington, D.C. 20418

Dr. Cyrus Klingsberg

Tech. Secretary

National Academy of Scientists

1 William A. Nixon

656 South I11inois Street

Arlington, Virginia 22204

2 Nuclear Fuel Services, Inc.

P. O. Box 124

West Valley, N. Y. 14171

J.P. Duckworth

W. G. Urban 
No. of

Copies

1

Nuclear Materials and Equipment Corporation (AEC)

Nuclear Design and Development

M. Selman, Manager

$1 \quad$ Nuclear Safety Associates

1055-R-Rockville Pike

Rockville, Md. 20852

W. A. Rodger

1

Nuclear Reactor Des. Sect.

Nuclear Power Plant Dept.

Hitachi, Ltd., Hitachi Works

Hitachi-Shi Ibaraki-Ken, Japan

A. Shimozato

4

Oak Ridge National Laboratory (AEC)

Central Research Library,

Document Reference Sect.

Central Research Library,

ORNL

Laboratory Records Dept.,

ORNL

Laboratory Records Dept.,

ORNL - RC

1

Plutonium Extraction P1ant

Marcoule, France

C. J. Jouannaud

1

Princeton University

Princeton, New Jersey

H. H. Hess

2

Radiation Protection Dept.

Luisenstrasse 46,

Bad Godesberg, West Germany

H. M. Holtzem

G. Straimer

1

$\frac{\text { Tokai Refinery }}{\text { At. Fue1 Corp. }}$

Tokai-Mura

Ibraki-Ken, Japan

M. Ichikawa 
No. of

Copies

2

Union Carbide Corporation (ORNL)

R. E. Blanco

M. E. What 1ey

1

$\frac{\text { University of Arizona }}{\text { Tucson, Arizona }}$

E. S. Simpson, Professor of Geology

1

University of Minnesota

Environmental Health Research and Training Center

Room 1108, Mayo Building

School of Public Health

Minneapolis, Minnesota

C. P. Straub

1

University of North Carolina

Chapel Hill, North Carolina

H. C. Thomas

1

University of Texas

Austin, Texas 78712

E. R. Gloyna

1

University of Wisconsin

Madison, Wisconsin 53715

H. Gladys Swope

2

U. S. Bureau of Mines

Washington, D.C

J. E. Crawford

J. W. Watkins

1

U. S. Geological Survey

Washington, D. C.

R. L. Nace

1

U. S. Public Health Service

Winchester, Massachusetts

D. Moelier

1 USDA National Agricultural Library

Current Serial Record (G)

Washington, D. C. 20250

1 Vanderbilt University

Nashville, Tennessee

P. A. Krenke1 
No. of

Copies

ONSITE-HANFORD

1

$\frac{\text { AEC Chicago Patent Group }}{\text { R. K. Sharp (Richland) }}$

3

$\frac{\text { AEC Richland Operations Office }}{\text { O. J. Elgert (2) }}$

C. L. Robinson

1

$\frac{\text { AEC RDT Site Rep., Richland }}{\text { A. D. Toth }}$

2

Atlantic Richfield Company

P. 0. Box 370

Richland, Washington 99352

H. C. Rathvon

L. L. Zahn

10

Atlantic Richfield Hanford Company

M. H. Campbe11

J. B. Fecht

R. E. Isaacson

L. M. Knights

W. P. McCue

G. C. Oberg

H. P. Shaw

P. W. Smith

R. E. Tom 1 inson

File Copy

3

Batte1le Memorial Institute

2 Douglas United Nuclear, Inc.

DUN File

51

Batte11e-Northwest

G. J. Alkire

J. M. Atwood

A. G. Blasewitz

W. R. Bond

R. E. Burns

R. L. Buschbom

C. R. Cooley

E. A. Coppinger

D. R. de Halas

G. M. Dalen

V. L. Hammond 


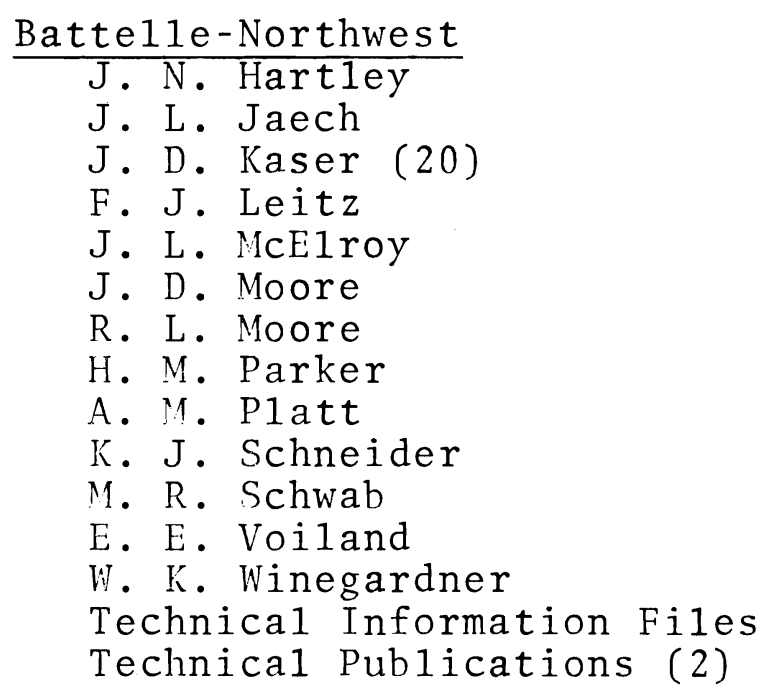

